\title{
Evaluation of vitamin C of ethno-wild edible plants in Northeast India
}

\author{
Khonamai Sewa Nakhuru ${ }^{1 *}$, Adani Lokho², Mridusmita Barman ${ }^{1}$, Jayshree Das ${ }^{1}$ \& Sanjai Kumar \\ Dwivedi $^{1}$ \\ ${ }^{1}$ Bio-resource Management Division, Defence Research Laboratory, Post Bag No. 02, Tezpur 784 001, India \\ ${ }^{2}$ Department of Botany, Siksha Bhavana, Visva-Bharati, Santiniketan 731 235, India \\ *Email: nakhuru12@gmail.com
}

\section{ARTICLE HISTORY}

Received: 25 January 2021

Accepted: 14 April 2021

Available online: 01 July 2021

KEYWORDS

Ethnic communities

North East India

Wild edible plant

Vitamin C

\section{ABSTRACT}

Ethnobotany deals with the usage of plants by different ethnic communities throughout the world for various purposes such as food, shelter, clothing, medicine, tools etc. North East India region is a part of eastern Himalayas with rich plant diversity. About 250 ethnic tribes inhabit the region with diverse cultures and traditional practices. Most of the ethnic communities in the region depend on natural resources directly for their daily needs and wild edible plants are one of them as they live in the vicinity of forests. This study deals with 20 wild edible plants, traditionally used by indigenous people. 18 genera belonging to 15 families with 3 species represented by family Lamiaceae. Different parts of plants are traditionally consumed as vegetables, of which 19 species represented with leaves as edible part. Berry, petiole and rootstalk constitute other edible parts. Most of the plant species were found to be rich source of vitamin C. Vitamin C content ranges from $6.24 \pm 0.34 \mathrm{mg}$ to $79.91 \pm 1.52 \mathrm{mg} / 100 \mathrm{~g}$ fresh weight and maximum was recorded in Alocasia indica (leaves) and Oxalis corniculata and the least in Tamarindus indica. The findings indicated that these ethno-botanicals can be grown in homestead as sources of vitamin $\mathrm{C}$ in regular diet.

\section{Introduction}

Northeast India (NEI) comprises of eight states viz. Assam, Arunachal Pradesh, Manipur, Meghalaya, Mizoram, Nagaland, Tripura and Sikkim. NEI lies between $21^{\circ} 34^{\prime} \mathrm{N}$ to $29^{\circ} 50^{\prime} \mathrm{N}$ latitude and $87^{\circ} 32^{\prime} \mathrm{E}$ to $97^{\circ} 52^{\prime} \mathrm{E}$ longitudes covering an area of $262060 \mathrm{sq} . \mathrm{km}$. The region is known for its richness in plant biodiversity, folk traditions and cultures. The region harbors about $50 \%$ of the flowering plants recorded in India. It is inhabited by more than 250 tribes of different ethnic groups and speaks about 200 dialects with distinct cultural entities and rich indigenous traditional knowledge; a paradise for ethnobotanists and anthropologists (1). The relationship between plants and human cultures is not only limited to the use of plants for food, clothing and shelter but include their uses for religious ceremonies, ornamentation and health care (2). The region is not only rich in cultures and traditions but abounds with different topography of varying climatic conditions suitable for fauna and flora to flourish making the whole communities directly or indirectly dependent upon its available natural resources for food, shelter, medicine etc. for their daily needs. There are hundreds of sacred groves in northeastern states viz. 101 in Arunachal Pradesh (3), 27 in Assam (4), 365 in Manipur (5), 111 in
Meghalaya (6) and 19 in Sikkim (7), which are directly associated with religious practices and community sense of conservation of threatened flora and fauna insitu conditions and act as a store house of innumerable medicinal plants, fruits, fuel wood etc. (8).

Wild edible plants (WEPs) are neither cultivated nor domesticated but growing in wild and are edible (9). There are about 800 different species of wild edible plants found in India, of which 300 species are used mostly by the tribal and rural population of the Northeastern region alone (10). The northeastern region is rich in wild edible plants and different parts of the plants, such as flower, fruit, leaf, stem, tuber, root etc. are consumed by different ethnic groups. There are several reports on WEPs of this region by various workers. The highest number of wild edible plants reported so far from this region is 628 species (11) consumed by Naga tribes residing in different parts of the biodiversity rich areas, Eastern Himalayas; 51 wild edible fruits from Mizoram (12); 61 WEPs from Tripura (13); 61 condiments and spices (14) and a total of 86 wild fruits (15) from Assam (16); 33 wild edible mushrooms from Nagaland (17); 22 wild edible mushrooms of Meghalaya (18); 384 wild food plants from Arunachal Pradesh $(19,20)$ and a total of 84 WEPs from Manipur $(21,22)$. Though there are a total of more

(c) Nakhuru et al (2021). This is an open-access article distributed under the terms of the Creative Commons Attribution License, which permits unrestricted use, distribution and reproduction in any medium, provided the original author and source are credited (https://creativecommons.org/licenses/by/4.0/) 
than one thousand species of WEPs from the northeastern states as reported by different researchers, only very few plants have been studied on the nutritional and other chemical compound aspects. Proximate nutritional compositions of 5 species viz. Brassaiopsis hainla, Gnetum gnemone, Pilea scripta, Rynchotechum ellipticum and Sarcochlamys pulcherrima from Manipur (23); 5 species from Arunachal Pradesh viz. Piper pedicellatum, Gonostegia hirta, Mussaenda roxburghii and Solanum spirale (24); 8 species from Meghalaya viz. Musa balbisiana, Talinum tringulare, Chenopodium album, Stellaria media, Vitex negundo, Leucas plukenetti, Paedaria foetida and Enhydra flutuans (25) and 15 species from Assam $(26,27)$.

Indigenous people are the custodian of these plant resources and the traditional knowledge associated with those plants (28). However, traditional knowledge is declining due to the influence of modern life and changes in land use patterns due to various anthropological developmental activities and encroachment of forest for agricultural practices for more food to feed the ever-increasing population.

Indigenous people have the knowledge of edible wild plants on when, where and how to gather and take either in raw form or by cooking and make various ethnic delicious dishes. WEPs are available in their natural habitats and some species within the vicinity of human inhabitants. In the past, people were heavily depended upon the wild plants to sustain themselves. However, the modern system of agricultural practices has afforded the choices to make of various food products that are commercially available thereby overlooking the necessity and importance of wild edible plants. On the other hand, commercially available crops make us depended on limited food sources thereby limit our dietary diversity which lead to nutrient deficiency and thereafter physiological problems and ailments. WEPs are lesser known to many; the reason of which could be due to non-availability or less palatability. However, these resources could be utilized for food security, either as emergency foods or as an integral part of our daily diet, as these are usually rich in vitamins and minerals than those of exotic or commercially available crops in the markets. Therefore, the present work is an attempt to substantiate the use of ethno-botanicals with scientific validation focusing on Vitamin $C$ content on 20 species of WEPs from northeast region to sustain the confidence of the consumers and promote the acceptability of the same among others. Vitamin $C$ is essential physiologically and as potent antioxidant, immunity booster to protect oneself from infectious diseases and healing from ageing and numerous diseases due to damage caused by free radicals and reactive oxygen species.

\section{Materials and Methods}

\section{Sample collection}

Ethnobotanical information and uses of the WEPs were gathered from the local people through personal interviews for the present study. 20 edible wild species were collected in April and May, 2020 from Tezpur, Sonitpur district of Assam, Northeast India. viz., Alocasia indica, Alpinia galanga, Amaranthus viridis, Alternanthera philoxeroides, Brassica juncea, Clerodendrum colebrookianum, Crassocephalum crepidioides, Houttuynia cordata, Lippia alba, Mentha spicata, Morus nigra, Murraya koenigii, Oxalis corniculata, Oxalis debilis, Plantago major, Polygonum microcephalum, P. benghalensis, Solanum nigrum, $S$. torvum and Tamarindus indica (Fig. 1 \& Table 1). Plant species were identified with the help of experts, local flora and literatures. Freshly collected vegetables were cleaned by soaking in water for about $30 \mathrm{~min}$. followed by rinsing in distilled water. External moistures were blotted dry with tissue paper followed by air drying briefly and non-edible portions were sorted and discarded. Edible portions of WEPs were chopped into small pieces and used for ascorbic acid analysis. Leaf and petiole of Alocasia indica were processed in the same manner, but separately and so also the leaf and rhizome of Houttuynia cordata.

\section{Chemicals}

Ascorbic acid and metaphosphoric acid were obtained from Sigma-Aldrich, Germany. 2,6 dichlorophenol indophenol was from Himedia, Mumbai.

\section{Vitamin C determination}

Ascorbic acid content was determined according to standard method (29). Ten (10) g sample in 3\% metaphosphoric acid was blended and final volume made upto $100 \mathrm{ml}$. Mixture was filtered using muslin cloth. $5 \mathrm{ml}$ of the extract/filtrate was titrated against 2, 6 dichlorophenol indophenol to light pink endpoint which persist for about $15 \mathrm{sec}$. Experiments were conducted in triplicates. Vitamin $\mathrm{C}$ content was calculated by the formula:

\section{Vitamin C (mg)/ $100 \mathrm{~g}=$}

Titre $\times$ Dye factor $\times$ Volume made up $\times 100$

Volume of extract taken $\times$ Weight of the sample taken

$$
\text { Where, dye factor }=\quad \begin{aligned}
& 0.5 \\
& \text { Titre }
\end{aligned}
$$

\section{Statistical Analysis}

Data were analyzed statistically using analysis of variance (ANOVA) and differences among the means were determined for significance using LSD (Least Significant Difference) test.

\section{Results and Discussion}

Selected 20 species of WEPs in the present investigation falls under 15 families and 18 genera, among which family Lamiaceae has maximum representative with three species viz., Mentha spicata, Clerondendrum colebrookianum and Pogostemon benganlensis while others are represented by either two or one species each (Fig. 1 \& Table 1). The detail information on recipes, part(s) used and modes of consumption by the ethnic communities in the region is presented in Table 1. Edible parts of WEPs constitute mostly leaf, stem, flower, fruit, rootstalk (Table 1). The present study 

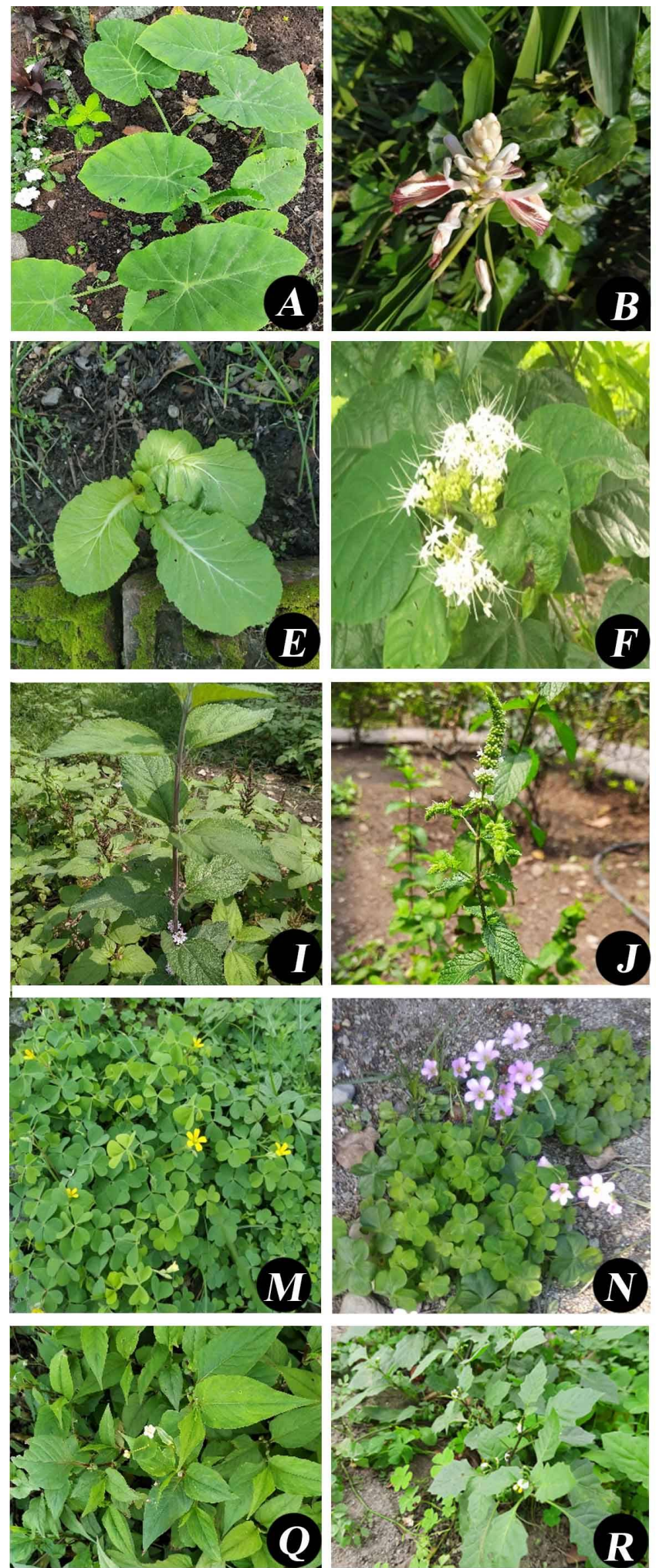
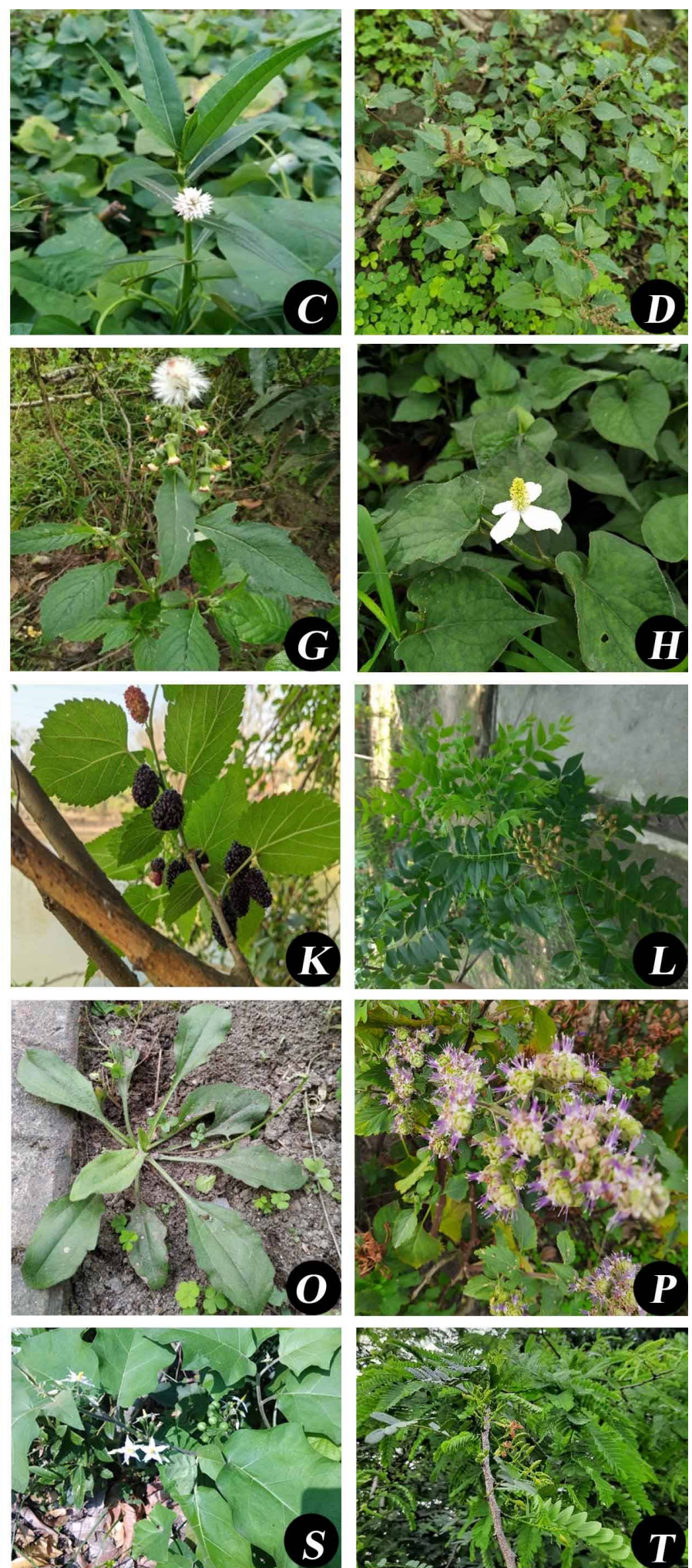

Fig. 1. Wild edible plants under natural habitats. (A) Alocasia indica, (B) Alpinia galanga, (C) Amaranthus viridis, (D) Alternanthera philoxeroides, (E) Brassica juncea, (F) Clerodendrum colebrookianum, (G) Crassocephalum crepidioides, (H) Houttuynia cordata, (I) Lippia alba, (J) Mentha spicata, (K) Morus nigra, (L) Murraya koenigii, (M) Oxalis corniculata (N) Oxalis debilis, (0) Plantago major, (P) Pogostemon benghalensis, (Q) Polygonum microcephalum (R) Solanum nigrum, (S) Solanum torvum \& (T) Tamarindus indica.

indicated that ethnic communities use more of leafy portion as vegetables besides petiole (Alocasia indica), rhizome/rootstalk (Houttuynia cordata) and berry fruit (Solanum torvum) as food. These WEPs plants are traditionally preferred as vegetables by the ethnic groups in the region. These plants can be grown hygienically in home/kitchen garden, harvested and cleaned to be consumed raw, except Alocasia indica, as salads and for garnishing curry or ethnic dish such as eromba or shingju to reap maximum health benefits. For example, Brassica juncea tender leaves are sorted into pieces and relished raw with chutney or eromba by some communities in Manipur. Food and health are strongly inter-related which can be observed in the usage of the same plant as food and remedy for ailments by indigenous folks (30). 
Table 1. List of wild edible plants, English \& local name, family, part use and recipe.

\begin{tabular}{|c|c|c|c|c|c|}
\hline $\mathbf{S} / \mathbf{N}$ & $\begin{array}{l}\text { Scientific name } \\
\text { English name }\end{array}$ & Local name & Family & $\begin{array}{l}\text { Part tested for } \\
\text { Vitamin C }\end{array}$ & Recipe \\
\hline 1 & $\begin{array}{l}\text { Alocasia indica (Roxb.) Schott. } \\
\text { Indo-Malayan Taro }\end{array}$ & $\begin{array}{l}\text { Yendem } \\
\text { (Meiteilon) }\end{array}$ & Araceae & Leaf, Petiole & $\begin{array}{l}\text { Leaves, petioles and rhizomes cooked with other } \\
\text { vegetables. }\end{array}$ \\
\hline 2 & $\begin{array}{l}\text { Alpinia galanga (L.) Willd. } \\
\text { Galangal }\end{array}$ & $\begin{array}{l}\text { Kanghu } \\
\text { (Meiteilon) }\end{array}$ & Zingiberaceae & Tender leaf & $\begin{array}{l}\text { Leaves and rhizomes cooked with fish and meat for } \\
\text { added taste. Finely chopped ones can be used for } \\
\text { garnishing curry or salad. }\end{array}$ \\
\hline 3 & $\begin{array}{l}\text { Alternanthera } \\
\text { philoxeroides (Mart.) Griseb. } \\
\text { Alligator weed }\end{array}$ & - & Amaranthaceae & Tender leaf & $\begin{array}{l}\text { Tender shoots and leaves cooked as vegetable. It is } \\
\text { added to curry for added taste. } \\
\text { Caution! Not to be taken regularly. }\end{array}$ \\
\hline 4 & $\begin{array}{l}\text { Amaranthus viridis L. } \\
\text { Slender amaranth }\end{array}$ & $\begin{array}{l}\text { Khutura } \\
\text { (Assamese) }\end{array}$ & Amaranthaceae & Tender leaf & Tender shoots and leaves cooked as vegetable. \\
\hline 5 & $\begin{array}{l}\text { Brassica juncea L. } \\
\text { Leaf mustard }\end{array}$ & $\begin{array}{l}\text { Hang gum } \\
\text { (Meiteilon) } \\
\text { Zha vu } \\
\text { (Poula) }\end{array}$ & Brassicaceae & Tender leaf & $\begin{array}{l}\text { Tender shoots and leaves consumed raw/boiled/cooked } \\
\text { with other items. }\end{array}$ \\
\hline 6 & $\begin{array}{l}\text { Clerodendrum colebrookianum } \\
\text { Walp. } \\
\text { East Indian glory bower }\end{array}$ & $\begin{array}{l}\text { Nou vu } \\
\text { (Poula) } \\
\text { Nefafu } \\
\text { (Assamese) }\end{array}$ & Lamiaceae & Tender leaf & $\begin{array}{l}\text { Tender leaves are boiled/ } \\
\text { cooked/fried with items such as potatoes, eggs, dry fish } \\
\text { etc. } \\
\text { Caution! kidney stone patient may take it with caution } \\
\text { as it has high oxalate content (Unpublished data). }\end{array}$ \\
\hline 7 & $\begin{array}{l}\text { Crassocephalum crepidioides } \\
\text { (Benth.) S. Moore } \\
\text { Fire weed }\end{array}$ & $\begin{array}{l}\text { Terapaibi } \\
\text { (Meiteilon) } \\
\text { Ba dai pou } \\
\text { (Poula) }\end{array}$ & Asteraceae & Tender leaf & $\begin{array}{l}\text { Tender shoots and leaves are consumed as salad/ } \\
\text { boiled/ cooked as vegetable. }\end{array}$ \\
\hline
\end{tabular}

Houttuynia cordata Thunb. $\quad \begin{aligned} & \text { Tuninkok } \\ & \text { (Meiteilon) }\end{aligned}$

8 Houttuynia cordata Thunb. $\begin{array}{ll}\text { (Meiteil } \\ \text { Chameleon plant }\end{array}$ (Poula) $\begin{array}{ll}\text { Saururaceae } & \text { Tender lea } \\ \text { Rhizome }\end{array}$

Tender leaves and rhizomes chopped finely and used for garnishing ethnic dish as eromba/ spicy chutney or cooked with other items.

\begin{tabular}{|c|c|c|c|c|c|}
\hline 9 & $\begin{array}{l}\text { Lippia alba (Mill.) N.E.Br. ex } \\
\text { Britton } \\
\text { \& P. Wilson } \\
\text { Bushy matgrass }\end{array}$ & $\begin{array}{l}\text { Naga mint (tribes } \\
\text { in Assam) }\end{array}$ & Verbenaceae & Tender leaf & $\begin{array}{l}\text { Tender shoots and leaves for flavoring curry or chutney } \\
\text { in raw/cooked. }\end{array}$ \\
\hline 10 & $\begin{array}{l}\text { Mentha spicata L. } \\
\text { Mint }\end{array}$ & $\begin{array}{l}\text { Noungshik hidak } \\
\text { (Meiteilon) } \\
\text { Pounghi } \\
\text { (Poula) }\end{array}$ & Lamiaceae & Tender leaf & $\begin{array}{l}\text { Tender shoots and leaves used for flavoring curry or as } \\
\text { chutney in raw. It can be consumed raw in case of } \\
\text { stomach pain. }\end{array}$ \\
\hline 11 & $\begin{array}{l}\text { Morus nigra L. } \\
\text { Black mulberry }\end{array}$ & $\begin{array}{l}\text { Houkourou shi } \\
\text { (Poula) }\end{array}$ & Moraceae & Tender leaf & $\begin{array}{l}\text { Tender leaves taken raw/ as vegetable. Fruits relished } \\
\text { fresh. }\end{array}$ \\
\hline 12 & $\begin{array}{l}\text { Murraya koenigii (L.) Spreng. } \\
\text { Curry leaf }\end{array}$ & $\begin{array}{l}\text { Narasingha } \\
\text { (Assamese) }\end{array}$ & Rutaceae & Tender leaf & $\begin{array}{l}\text { Tender twigs and leaves for flavoring } \\
\text { curry/salad/pickle. }\end{array}$ \\
\hline 13 & $\begin{array}{l}\text { Oxalis corniculata L. } \\
\text { Yellow woodsorrel }\end{array}$ & $\begin{array}{l}\text { Nahtimai tah } \\
\text { (Poula) } \\
\text { Lam yensil } \\
\text { (Meiteilon) }\end{array}$ & Oxalidaceae & Tender leaf & $\begin{array}{l}\text { Tender aerial parts for flavoring curry, salad etc } \\
\text { Caution! kidney stone patient may take it with caution } \\
\text { as it has high oxalate content (Unpublished data). }\end{array}$ \\
\hline 14 & $\begin{array}{l}\text { Oxalis debilis Kunth. } \\
\text { Pink sorrel }\end{array}$ & $\begin{array}{l}\text { Bar tengasi } \\
\text { (Assamse) } \\
\text { Yensil } \\
\text { (Meiteilon) }\end{array}$ & Oxalidaceae & Tender leaf & $\begin{array}{l}\text { Wrapped the tender leaves in banana leaf and burnt } \\
\text { under hot ash and relished. Leaves added to curry or } \\
\text { salad for added taste. } \\
\text { Caution! kidney stone patient may take it with caution } \\
\text { as it has high oxalate content (Unpublished data). }\end{array}$ \\
\hline 15 & $\begin{array}{l}\text { Plantago major L. } \\
\text { Greater plantain }\end{array}$ & $\begin{array}{l}\text { Vearou nah vu } \\
\text { (Poula) }\end{array}$ & Plantaginaceae & Tender leaf & Tender leaves are cooked as vegetable. \\
\hline 16 & $\begin{array}{l}\text { Pogostemon benghalensis } \\
\text { (Burm.f.) Kuntze- }\end{array}$ & $\begin{array}{l}\text { Lamgi thoid- ing } \\
\text { (Meiteilon) } \\
\text { Suklati } \\
\text { (Assamese) }\end{array}$ & Lamiaceae & Tender leaf & $\begin{array}{l}\text { Tender leaves are cooked as vegetable. Leaves are used } \\
\text { for preparing pakora. }\end{array}$ \\
\hline 17 & $\begin{array}{l}\text { Polygonum microcephalum } \\
\text { D. Don. }\end{array}$ & $\begin{array}{l}\text { Madhu-saleng } \\
\text { (Assamese) }\end{array}$ & Polygonaceae & Tender leaf & $\begin{array}{l}\text { Tender leaves are chopped and used for flavoring } \\
\text { curry/ cereals. It can be chopped and used for } \\
\text { garnishing salad. } \\
\text { Caution! Not to be taken regularly as it has high oxalate } \\
\text { content (Unpublished data). }\end{array}$ \\
\hline 18 & $\begin{array}{l}\text { Solanum nigrum L. } \\
\text { Black nightshade }\end{array}$ & $\begin{array}{l}\text { Hou heithou shi } \\
\text { (Poula) }\end{array}$ & Solanaceae & Tender leaf & $\begin{array}{l}\text { Leaves are cooked as vegetable and ripened fruits } \\
\text { relished raw. }\end{array}$ \\
\hline 19 & $\begin{array}{l}\text { Solanum torvum Sw. } \\
\text { Pea eggplant } \\
\text { Devil's fig }\end{array}$ & $\begin{array}{l}\text { Khou thou shu } \\
\text { shidupu } \\
\text { (Poula) }\end{array}$ & Solanaceae & Berry & $\begin{array}{l}\text { Berries are cooked and taken as chutney with } \\
\text { fermented fish. It is taken raw for smooth bowel } \\
\text { movement. } \\
\text { Caution! Not to be taken regularly. }\end{array}$ \\
\hline 20 & $\begin{array}{l}\text { Tamarindus indica } \mathrm{L} \text {. } \\
\text { Tamarind }\end{array}$ & $\begin{array}{l}\text { Mange } \\
\text { (Meiteilon) } \\
\text { Teteli } \\
\text { (Assamese) }\end{array}$ & Caesalpiniaceae & Tender leaf & $\begin{array}{l}\text { Tender leaves or fruits are given to curry for added } \\
\text { taste. Tender leaves are used for garnishing salad. } \\
\text { Fruits as refreshing drink in summer with added taste. }\end{array}$ \\
\hline
\end{tabular}

Meiteilon : language of Manipuri, Poula : dialect of Poumai (a tribe of Manipur state) 
This is reflected in the present study where almost all the plants investigated are used as food and medicine at the same time (Table 1). Vitamin $C$ is one of the essential nutritional components as it acts as natural antioxidant and need to be taken through diet or supplement. It cannot be synthesized in human body (31). Keeping in mind the roles played by vitamin $C$ in health and diseases in human body, this study was undertaken to determine vitamin $\mathrm{C}$ content in commonly use wild edible plants. These plants can be broadly categorized into three groups based on Vitamin C content (Table 2) viz., high, moderate and low.

\section{High Vitamin C}

Leaves and petiole of $A$. indica are widely used as vegetable either fresh or in dried form by different communities in Manipur. The petiole is consumed as a blood purifier and the leaf is used for treating boils. It is hepatoprotective, antioxidant, analgesic, antiarthritic, anti-inflammatory, anti-tumour and antipyretic (32). A. indica corm/tuber possessed both ascorbic acid (76.65 mg/100 g) and alpha-tocopherol (69.54 mg/100 g) on fresh weight (33). These vitamins are most commonly found in vegetables and act synergistically as a potent antioxidant, thus, preventing cellular damage caused by free radicals and reactive oxygen species (33). Present study revealed that $A$. Indica leaf contain higher vitamin $C$ $(79.91 \pm 1.52 \mathrm{mg} / 100 \mathrm{~g})$ than tuber $(76.65 \mathrm{mg} / 100 \mathrm{~g})$ (33) and has the highest content of Vitamin C among the undertaken WEPs. A. indica petiole has $11.07 \pm$ $0.39 \mathrm{mg} / 100 \mathrm{~g}$ fresh weight. Oxalis species viz., $O$. corniculata $(77.69 \pm 1.05 \mathrm{mg} / 100 \mathrm{~g})$ and $O$. debilis $(56.60 \pm 0.39 \mathrm{mg} / 100 \mathrm{~g})$ showed the second highest content of vitamin C. These species are used by indigenous people in NEI for treating different ailments, for instance, $O$. corniculata is used for treating diarrhea and dysentery by Poumai-Naga and O. debilis is used against gastritis by people of Assam.

Table 2. Vitamin C content in wild edible plants.

\begin{tabular}{rlc}
\hline \multicolumn{1}{c}{$\begin{array}{l}\text { no. } \\
1\end{array}$} & Scientific name & Vitamin C (mg/100 g) \\
\hline 2 & A. indica (Petiole) & $79.91 \pm 1.52^{\mathrm{r}}$ \\
\hline 3 & Alpinia galanga & $11.07 \pm 0.34^{\mathrm{e}}$ \\
\hline 4 & Alternanthera philoxeroides & $20.81 \pm 0.39^{\mathrm{h}}$ \\
\hline 5 & Amaranthus viridis & $34.52 \pm 0.39^{\mathrm{n}}$ \\
\hline 6 & Brassica juncea & $23.58 \pm 0.79^{\mathrm{i}}$ \\
\hline 7 & Clerodendrum colebrookianum & $54.58 \pm 0.36^{\circ}$ \\
\hline 8 & Crassocephalum crepidioides & $14.05 \pm 0.36^{\mathrm{g}}$ \\
\hline 9 & Houttuynia cordata & $07.64 \pm 0.39^{\mathrm{b}}$ \\
\hline 10 & H. cordata (Rhizome) & $24.36 \pm 0.34^{\mathrm{j}}$ \\
\hline 11 & Lippia alba & $10.09 \pm 0.39^{\mathrm{d}}$ \\
\hline 12 & Mentha spicata & $07.11 \pm 0.39^{\mathrm{b}}$ \\
\hline 13 & Morus nigra & $07.48 \pm 0.39^{\mathrm{b}}$ \\
\hline 14 & Murraya koenigii & $34.16 \pm 0.39^{\mathrm{n}}$ \\
\hline 15 & Oxalis corniculata & $25.69 \pm 0.39^{\mathrm{k}}$ \\
\hline 16 & Oxalis debilis & $77.69 \pm 1.05^{\mathrm{q}}$ \\
\hline 17 & Plantago major & $56.6 \pm 0.39^{\mathrm{p}}$ \\
\hline 18 & Pogostemon benghalensis & $11.9 \pm 0.39^{\mathrm{f}}$ \\
\hline 19 & Polygonum microcephalum & $14.09 \pm 0.34^{\mathrm{h}}$ \\
\hline 20 & Solanum nigrum & $29.38 \pm 0.34^{\mathrm{l}}$ \\
\hline 21 & Solanum torvum (Berry) & $08.43 \pm 0.39^{\mathrm{m}}$ \\
\hline 22 & Tamarindus indica & $06.24 \pm 0.39^{\mathrm{c}}$ \\
\hline & & \\
\hline
\end{tabular}

Values are represented as mean \pm standard deviation of triplicate analysis. Means with different letter(s) in the same column indicate significant differences at $\mathrm{p} \leq 0.05$.
B. juncea is a semi-cultivated species and one of the most popular leafy vegetables consumed by every house-hold in its season in Manipur. B. juncea leaves are one of the highest sources of vitamin $\mathrm{K}$ among the leafy vegetables and low in calories and fats with a rich source of phytochemicals. Moreover, mustard leaves are source of vitamin $\mathrm{C}$, several essential minerals such as calcium, iron, magnesium, potassium, zinc, selenium and manganese (34). Leaf of $B$. juncea was found to contain high amount of vitamin C (54.58 $\pm 0.36 \mathrm{mg} / 100 \mathrm{~g})$.

\section{Moderate Vitamin C}

The young and tender leaves of mulberry ( $M$. nigra) are used as vegetable by two ethnic communities (Naga and Kuki) in Manipur. It is also used as feeds for silk worm culture in sericulture. Ripened fruits are relished fresh and used for making jam. In the present investigation, $M$. nigra leaves were found to contain sufficient amount of vitamin C (34.16 \pm 0.39 $\mathrm{mg} / 100 \mathrm{~g})$. Turkish mulberry fruits (M. alba, M. nigra, and $M$. rubra) ascorbic acid content ranges from 19.4 to $22.4 \mathrm{mg} / 100 \mathrm{ml}$ (35). $H$. cordata whole plant is consumed as vegetables by different ethnic communities. The leaves and rootstalks are consumed either raw or cooked. Rhizomes/rootstalks are preferred over its leaves for making ethnic special spicy chutney with other ingredients among the folks in Manipur, whereas leaves are more popular among ethnic groups in Assam. The plant is anti-infectious and anti-inflammatory $(36,37)$ and also used for treating measles, gonorrhoea, skin ailments, anti-tumour, pneumonia, bronchitis, stomach ulcer $(38,39)$. While analyzing the vitamin $C$ content on leaves and rhizomes, leaves showed higher value $(24.36 \pm 0.34 \mathrm{mg} / 100 \mathrm{~g})$ than the rhizomatous parts $(10.09 \pm 0.39 \mathrm{mg} / 100 \mathrm{~g})$. Dried leaves were reported with $15.23 \mathrm{mg} / 100 \mathrm{~g}$ (40). Many communities in Manipur prefer rhizome over leaves and leaves are usually ignored. However, from the present findings the leaves should be preferred over rhizomatous roots and can also be harvested frequently. By doing so it can be protected from uprooting from its natural habitats which is not the sustainable way of harvesting of WEPs. Also, it justifies its uses against infections, as the vitamin $C$ is known to be a potent non-enzymatic antioxidant and known to enhance immunity. A. philoxeroides is a common WEP and often sighted at the local markets consumed as vegetable by the people of Assam, though, it is not popular among other communities of NE states. A. philoxeroides possesses high nutritional and low anti-nutritional factors and therefore recommended to be included in the diet (41). However, it is reported to accumulate heavy metals (42) by other researchers and therefore it could pose health hazards. It was observed to have high content of vitamin C (34.52 $\pm 0.39 \mathrm{mg} / 100 \mathrm{~g})$ as compared to findings (41). Leaf and corm of $A$. galanga are commonly used as spices or condiments in nonvegetable food items by Naga communities. The plant is used for treating dyspepsia, fevers, incontinence of urine, halitosis and voice hoarseness in throat infections (43). A. galanga is available in the forests of $\mathrm{NE}$ region and the leaves are found to contain a moderate amount of vitamin C $(20.81 \pm 0.39 \mathrm{mg} / 100$ g). A. viridis is a very popular leafy vegetable 
commonly available in the paddy field or furrow land and the tender shoots are harvested and sold at local markets. It tastes at its best in March-April, though it is available almost throughout the year. A. viridis is an excellent source of protein. The amino acid composition of the plant is comparable to that of a World Health Organization (WHO) protein standard. Two fatty acids (linoleic and a-linolenic) essential for humans and number of minerals including iron, magnesium, calcium and zinc were also reported (44). Leaves of $A$. viridis showed low vitamin C (23.58 $\pm 0.79 \mathrm{mg} / 100 \mathrm{~g})$ as compared to $(106.64 \mathrm{mg} / 100 \mathrm{~g}$ fresh weight) (45). S. nigrum leaves are cooked as vegetable and the ripened berries are eaten raw. Content of vitamin $\mathrm{C}$ in leaves was estimated to be $30.43 \pm 0.39 \mathrm{mg} / 100 \mathrm{~g}$ on fresh weight which is slightly lower than value reported earlier (35.18 $\mathrm{mg} / 100 \mathrm{~g}$ ) (46). C. colebrookianum is widely used as vegetable by different ethnic groups in the northeastern region. Leaves are either boiled/cooked with dry fish or meat and consumed. It is widely used as a home remedy for hypertension by North East people. It is found to be practically non-toxic (47). Vitamin $C$ content in the leaves of $C$. colebrookianum was $14.05 \pm 0.36 \mathrm{mg} / 100 \mathrm{~g}$. M. koenigii is widely used as spice or flavor in curry, salad, chutney, pickle etc. It is used for treating nausea, vomiting, diarrhea, dysentery, blood purification, tonic and stomachic (48). Leaves were found to contain moderate vitamin $\mathrm{C}(25.69 \pm 0.39 \mathrm{mg} / 100 \mathrm{~g}$ fresh weight $)$ as compared to the reported (815 $\pm 0.80 \mathrm{mg} / 100 \mathrm{~g}$ dry weight) (49). $P$. microcephalum leaves are used as souring agent in the curry by the ethnic people. It was found to have $29.38 \pm 0.39 \mathrm{mg} / 100 \mathrm{~g}$ in fresh weight vitamin C. $P$. benghalensis leaves are used as vegetable, also in preparing side-dish like "pakora" by the ethnic communities. Leaves are cooked and given for clearing uterus to women post-delivery by ethnic groups in Assam and root for treating fever (50). Vitamin C content in leaf of $P$. benghalensis was 14.09 $\pm 0.3 \mathrm{mg} / 100 \mathrm{~g}$. $P$. major is used throughout the world for treating several diseases such as skin diseases, infectious problems related to digestive organs, respiratory organs, reproduction, blood circulation, anti-tumour, pain relief and reducing fever (51). In India, different ethnic groups use it for treating diarrhoea, dysentery, ulcer, urinary tract infections, bee stings, pus-formation in impetigo, diurectic, stimulant (52); anti-inflamatory (53); cuts and wounds (54); menstrual disorders (55); astringent effects (56). Ethnic communities from the north east region use it for various purposes. Its leaves are used as vegetable and ethno-medicine by indigenous people. It is commonly available in the fields. Naga tribes use it as a haemostatic on wounds and cuts (57); Khasi tribe uses it for treating burns (58); People of Assam and Arunachal use it for treating any inflammatory ailment (59). P. major leaf was found to contain moderate amount of vitamin C (11.9 \pm 0.39 $\mathrm{mg} / 100 \mathrm{~g}$ ) as compared to the other wild edible plants undertaken for the study.

\section{Low Vitamin C}

Tamarindus indica, also known as tamarind, is extensively used by different ethnic communities in the world as food and traditional medicines for its wide array of applications; leaves and flowers as vegetables, fruit pulp for seasoning of food, jam and sweets, refreshing drinks and also fermented into alcoholic beverage (60). $T$. indica leaves are consumed as vegetable by ethnic communities in NEI and vitamin $C$ content of the same was analyzed to be nominal ( $6.24 \pm 0.34 \mathrm{mg} / 100 \mathrm{~g})$. Leaves of $M$. spicata is traditionally used as condiment and as medicine for treating stomach upset and indigestion by ethnic groups in the region. Vitamin $\mathrm{C}$ content in leaves of $M$. spicata was found to be $7.48 \pm 0.39 \mathrm{mg} / 100 \mathrm{~g}$ which is low as compared to other plants in the present study. It is used for treating flatulence, bronchitis, anorexia, nausea, liver complaints (61). The berries of $S$. torvum are used as vegetable as well as ethnomedicine by Naga, Mizo, Khasi, Assamese, Manipuri, Tripuri etc. for treating fever, diabetes, blood pressure and headache. In Indonesia, it is considered one of the best vegetable side-dishes with rice. Traditional uses reported are: roots poultice for cracks in the feet, seeds are smoked for toothache (Malaysia), antitussive (China), extract as insects sting, fruits as remedy for stomach pain (India) (62). Vitamin C content in berries was $8.44 \pm 0.39 \mathrm{mg} / 100 \mathrm{~g}$. However, as high as $11.62 \pm 1.49 \mathrm{mg} / \mathrm{g}$ fresh weight in young fruits was reported. Ascorbic acid content in young fruits is higher than mature fruits (63). L. alba is a spice used by different ethnic communities of Assam and Nagaland. Vitamin C content in leaves was $7.11 \pm 0.39 \mathrm{mg} / 100 \mathrm{~g}$. Essential oils from its leaf is used as insect repellants. Other ethnic communities from different parts of the world use the plant for various ailments such as stomachache, indigestion, liver diseases, syphilis, diarrhea, menstrual disorders, sedatives and antimalarial and respiratory ailments (64-66). C. crepidioide leaves are taken as vegetable or consumed raw as salad by different ethnic groups in the region. It is used as remedy for gastritis, to arrest bleeding in cuts and wounds and quick healing by Poumai and Mao communities in Manipur. Vitamin C content of its leaves was $7.64 \pm$ $0.39 \mathrm{mg} / 100 \mathrm{~g}$ in fresh weight which is more or less the same as reported (9.17 $\mathrm{mg} / 100 \mathrm{~g})$ (67). During Covid-19 pandemic lockdown, the villagers in NE India joined the fight for controlling Covid-19 by supplying fresh wild vegetables to urban dwellers (68) thereby mitigating the short supply of fresh vegetables.

\section{Conclusion}

The findings of the present investigations confirmed that the studied ethno-wild edible plants served as foods and herbal medicines for the ethnic communities in NE India. Consumption of these 20 WEPs should be encouraged among the ethnic groups, in particular and public in general, by creating awareness about the benefits of its important constituents like vitamin $\mathrm{C}$, which is essential for health and prevention of diseases. Among the ethno-wild edible plants, species with high content of vitamin $C$ (as shown in Table 1 . such as $A$. indica, O. corniculata, O. debilis, B. juncea, $A$. philoxeroides, S. nigrum, $P$. microcephalum, $M$. koenigii, $M$. indica, M. alba, A. viridis and A. galanga) should be focused upon to cater the daily requirement of vitamin $\mathrm{C}$ in the diets for the poor 
and needy people. On the other hand, several species (C. colebrookianum, C. crepidioides, H. cordata, L. alba, M. spicata, P. major, S. torvum and T. indica) play dual roles in providing not only the essential nutrients or minerals supplement but also as a source of medicine for the ethnic communities. WEPs are the source of food security during emergency situations for the larger populace in the region. Therefore, the WEPs should be preserved and over exploitation from its natural habitats should be discouraged in order to maintain its germplasm for future use and development as food supplements. Global agriculture focuses on a few cultivars, usually of high yielding varieties which are costly and not affordable by poor people. Therefore, WEPs meet their daily requirement of minerals and vitamins. Moreover, these plants can be easily home grown for management or prevention of many ailments and chronic diseases at an affordable cost and for commercial production as well for an additional income for the indigenous population in the region. Lastly, the findings of this study would be helpful for researchers to carry out further studies related to nutritional supplement, biological and pharmacological functions of these plants.

\section{Acknowledgements}

Authors are grateful for the fund from DRDO headquarters, New Delhi. Also, we are grateful to all the local people for their corporation and sharing their valuable knowledge for the present study.

\section{Authors' contributions}

KSN conceived of the study and participated in its design and coordination. MB carried out the experiments. KSN and AL participated in drafting and JD and SKD participated in editing the manuscript. All authors read and approved the final version of the manuscript.

\section{Conflict of interests}

Authors declare no conflict of interests.

\section{References}

1. Mao AA, Roy DK. Ethnobotanical studies in North East India: A Review. In: Jain AK, editor. Indian Ethnobotany: Emerging Trends. Jodhpur: Scientific Publishers (India); 2016. p.99-112.

2. Schultes RE. Ethnobotany and technology in northwest Amazon: A partnership. Pages 7-13 In: Plotkin, MJ, Famolare, LM, (eds). Sustainable Harvest and Marketing of Rain Forest Products. Washington DC: Island Press;1992.p.7-13.

3. Khan ML, Arunachalam A, Barbhuiya AR. Web-GIS Digital Atlas of the Sacred Groves of the North-East India: Pilot study with Sacred Groves of Arunachal Pradesh. Sanction No. DSIR/ Web/TIF026/2004-2005): 2004. Department of Scientific and Industrial Research, Ministry of Science and Technology, Govt. of India. Technical Report.

4. Medhi P, Borthakur SK. Sacred groves and sacred plants of the Dimasas of North Cachar Hills of Northeast India. African J Plant Sci. 2013;7:67-77. https://doi.org/10.5897/AJPS12.038
5. Devi OA, Das M, Saikia A, Das P. Ascorbic acid and tocopherol content of ten medicinal plant extracts of Manipur having antiinflammatory properties. Int J Home Sci. 2016;2(1):308-12.

6. Singh B, Sinha BK, Singh VN, Hynniewta TM. Botanical Survey of India, Kolkata: 2007. Meghalaya ke Pavan Van (Sacred groves): Ek Vigyanic Aadhdhyan Vanaspati Vaani.

7. Government of Sikkim. Forests, Environment and Wildlife Management Department. Sacred Groves of Sikkim. The Department, 2011.

8. Upadhyay KK, Japang B, Singh SS, Tripathi SK. Status and socio-ecological dimensions of sacred groves in Northeast India. J Appl Nat Sci. 2019;11(3):590-95. https://doi.org/10.31018/jans.v11i3.2121

9. Beluhan S, Ranogajec A. Chemical composition and nonvolatile components of Croatian wild edible mushrooms. Food Chemistry. https://doi.org/10.1016/j.foodchem.2010.07.081

10. Hazarika TK, Pongener M. Potential wild edible fruits of Nagaland, North-east India and its significance in the livelihood and nutritional security of rural, indigenous people, Genet Resour Crop Evol. 2018;65:99-215. https://doi.org/10.1007/s10722-017-0523-3

11. Pfoze NL, Kehie M, Kayang H, Mao AA. Estimation of ethnobotanical plants of the Naga of North East India. J Med Pl Studs. 2014;2(3):92-104.

12. Laha R, Lalhriatpuia, Lalmuanpuii R, Ralte L, Lalremruata PC. Diversity and ethnobotanical uses of wild edible fruits in Mizoram, Northeast India. Int J Pharm Bio Sci. 2018;8(2):13242.

13. Chanda M, Pal I, Majumder S, Datta P. Assessment of traditionally used wild edible plants and its impact on health and livelihood among the ethnic communities of Tripura. Asian J Agr Hort Res. 2018;2(3):1-13. https://doi.org/10.9734/AJAHR/2018/44724

14. Bharali P, Sharma CL, Singh B, Sharma M. Ethnobotanical studies of spice and condiment plant used by some communities of Assam. Int J Adv Sci Res. 2017;3(1):1-11. https:/ doi.org/10.7439/ijasr.v3i1.3843

15. Brahma S, Narzary H, Basumatary S. Wild edible fruits of Kokrajhar districts of Assam, Northeast India. Asian J Plant Sci Res. 2013;3(6): 95-100.

16. Saikia M. Wild edible fruits consumed by people of Upper Assam, NE India. World J Pharm Sci. 2015;3(6):1138-44.

17. Ao T, Deb CR, Khruomo N. Wild edible Mushrooms of Nagaland: A potential food resource. J Exp Bio Agr Sci. 2016;4(1):60-65. https://doi.org/10.18006/2015.4(1).59.65

18. Kalita K, Bezbaroa RN, Kumar R \& Pandey S. Documentation of wild edible mushrooms from Meghalaya, Northeast India. Cur Res Environ Appl Mycol. 2016;6(4):238-47. https://doi.org/10.5943/cream/6/4/1

19. Saha D, Sundriyal M, Sundriyal RC. Diversity of food composition and nutritive analysis of edible plants in a mutiethnic tribal land, Northeast India: an important facet for food supply. Indian J Trad Knowl. 2014;13(4):698-705.

20. Dutta G, Baruah G, Devi A. Wild food plants of Mishing tribe: An ethnobotanical survey. Trop Pl Res. 2016;3(1):221-23.

21. Pfoze NL, Kumar Y, Sheikh N, Myrboh B. Assessment of local dependency on selected wild edible plants and fruits from Senapati district, Manipur, Northeast India. Ethnobot Res App. 2012; 10: 357-67. https://doi.org/10.17348/era.10.0.357-367

22. Devi AK, Khan ML, Tripathi RS. Sacred groves of Manipur, Northeast India: biodiversity value, status and strategies for their conservation. Biodiversity Conservation. 2005;14:1541-82. https://doi.org/10.1007/s10531-004-0530-5

23. Panmei R, Gajurel PR, Singh B. Ethnobotany and Nutritional values of some selected wild edible plants used by Rongmei tribe of Manipur Northeast India. Int J Appl Bio Pharm Tech. 2016;7(4):1-7. 
24. Kalita P, Tag H, Sarma HN, Das AK. Evaluation of nutritional potential of five unexplored wild edible food plants from Eastern Himalayan biodiversity hotspot region (India). Int J Nutr Food $\quad$ Engg. $\quad 2014 ; 8(3): 215-18$ https://doi.org/10.5281/zenodo.1091224

25. Chandra KS, Gogoi D, Gautum KH, Handique AK. Nutritive values of some non-conventional leafy vegetables and scarcity food plants of north east India. African J Food Sci. 2016;10(1): 340-43. https://doi.org/10.5897/AJFS2016.1427

26. Terangpi R, Basumatary R, Teron R. Nutritional consideration of three important emergency food plants studied among Karbi tribe of North east India. J Sci Inn Res. 2015; 4(3):138-41.

27. Narzary H, Swargiary A, Basumatary S. Proximate and vitamin $\mathrm{C}$ analysis of wild edible plants consumed by Bodos of Assam,

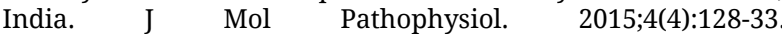
https://doi.org/10.5455/jmp.20151111030040

28. Demel T, Abeje E. Status of indigenous fruits in Ethiopia, In: Chikamai B, EyogMatig O, Mbogga, (ed). Review and appraisal on the status of indigenous fruits in Eastern Africa, IPGRISAFORGEN, AFREA/FORNESSA

29. Ranganna S. A handbook of analysis and quality control for fruits and vegetable products. Delhi: Tata McGrow Hill Education Pvt Ltd;1986.

30. Singh MK, Paul J, De T, Chakraborti T. Bioactivity guided fractionation of Moringa oleifera Lam. flower targeting Leishmantadonovani. Indian J Exp Biol. 2015;53:747-53.

31. Nishikimi M, Fukuyama R, Minoshima S, Shimizu N, Yagi K. Cloning and chromosomal mapping of the human nonfunctional gene for L-gulono-gamma-lactone oxidase, the enzyme for L-ascorbic acid biosynthesis missing in man. J Biol Chem. 1994;269:13685-88. https://doi.org/10.1016/S0021 9258(17)36884-9

32. Patil SH, Sreenivas SA, Deshmukh PV, Srikanth M, Choudhury A, Wagh AE, Anthelminthic activity of Alocasia indica Schott. root stocks. Int J Drug Dev Res.2012;4 (4):211-14.

33. Basu S, Das M, Sen A, Choudhury UR, Datta G. Analysis of complete nutritional profile and identification of bioactive components present in Alocasia indica tuber cultivated in Howrah District of West Bengal, India. Asian Pac J Trop Med. 2014;7(1):527-33. https://doi.org/10.1016/S1995-7645(14)60285-6

34. Banerjee A, Datta JK, Mondal NK. Biochemical changes in leaves of mustard under the influence of different fertilizers and cycocel. J Agri Tech. 2012;8(4):1397-1411.

35. Ercisli S, Orhan E. Chemical composition of white (Morus alba), red (Morus rubra) and black (M. nigra) mulberry fruits. Food Chem. https://doi.org/10.1016/j.foodchem.2006.10.054 2007;103(4):1380-84

36. Hayashi K, Kamiya M, Hayashi T. Virucidal effects of the steam distillate from Houttuynia cordata and its components on HSV 1, influenza virus and HIV. Planta Medica.1995;61(3):237-41. https://doi.org/10.1055/s-2006-958063

37. Woranam K, Senawong G, Utaiwat S, Yunchalard S, Sattayasai J, Senawong T. Anti-inflammatory activity of the dietary supplement Houttuynia cordata fermentation product in RAW264.7 cells and Wistar rats. PLOS ONE. 2020;15(3). https://doi.org/10.1371/journal.pone.0230645

38. Wang JH, Bose S, Shin NR, Chin YW, Choi YH, Kim H. Pharmaceutical impact of Houttuynia cordata and metformin combination on high-fat-diet-induced metabolic disorders: link to intestinal microbiota and metabolic endotoxemia. Front Endocrinol.

https://doi.org/10.3389/fendo.2018.00620

2018;9:620

39. Khongsai M, Saikia SP, Kayang H. Ethnomedicinal plants used by different tribes of Arunachal Pradesh. Indian J Tradit Knowl. 2011;10(3):541-46.

40. Devi OA, Das M, Saikia A, Das P. Ascorbic acid and tocopherol content of ten medicinal plant extracts of Manipur having antiinflammatory properties. Int J Home Sci. 2016;2(1):308-12. https://doi.org/10.22271/23957476
41. Preetha TS, Anju S, Anikumar S, Mini I. Nutritional analysis of selected species of Alternanthera Forsskal (Amaranthaceae). Indian J Exp Biol. 2018 (5):48-53.

42. Khankhane P J, Kumar S, Bisen, H S. Heavy metal extracting potential of common aquatic weeds. Indian J Weed Sci. 2014; 46(4):361-63.

43. Nadkarni KM. Indian Materia Medica. Popular Prakashan, Bombay. 1976;1:1142. https://doi.org/10.1136/bmj.1.6018.1142

44. Sena LPV, Anderjagt DJ, Rivera CT, Sin AT, Muhamadu I et al. Analysis of nutritional components of eight famine foods of the Republic of Niger. Plant Foods Hum Nutr. 1998;52(1):17-30. https://doi.org/10.1023/A:1008010009170

45. Sarker U, Oba S. Nutraceuticals, antioxidant pigments, and phytochemicals in the leaves of Amaranthus spinosus and Amaranthus viridis weedy species. Scientific Reports. 2019;9: 20413. https://doi.org/10.1038/s41598-019-50977-5

46. Akubugwo IE, Obasi AN, Ginika SC. Nutritional potential of the leaves and seeds of black nightshade- Solanum nigrum L. var virginicum from Afikpo-Nigeria. Pakistan J Nutri. 2007;6(4): https://doi.org/10.3923/pjn.2007.323.326

47. Kotoky J, Gupta B D, Deka N. Pharmacological studies of Clerodendron colebrookianum Walp., a potent hypotensive plant. Indian J Physiol Pharmacol. 2005;49 (3):289-96.

48. Ajay S, Rahul S, Sumit G et al. Comprehensive review: Murraya koenigii Linn. Asian J Pharm Life Sci. 2011;1:417-25.

49. Uraku AJ, Nwankw VO. Phytochemical and nutritional composition analysis of Murraya koenigii Linn. leaves. British J Pharm Res. 2015;6(3):174-80. https://doi.org/10.9734/BJPR/2015/15595

50. Dangol. Traditional uses of plants of commonland habitats in western Chitwan, Nepal. J Inst Agri Anim Sci. 2008;29:71-78.

51. Samuelsen AB. The traditional uses, chemical constituents and biological activities of Plantago major. J Ethnopharmacol. 2000;71(1-2):1-21. https://doi.org/10.1016/S0378-8741(00)00212-9

52. Joshi DN, Sah BCL, Suri RK. Some medicinal plants of Rudranath Bugyal, Chamoli, U P. Bulletin Medico-ethno-bot Res. 1982;3:27-42.

53. Jain SK. Dictionary of Indian Folk Medicine and Ethnobotany. New Delhi: Deep Publications; 1991

54. Saklani A, Jain SK. Ethnobotanical observations on plants used in northeastern India. Int J Crude Drug Res. 1989;27:65-73. https://doi.org/10.3109/13880208909053940

55. Fazal U. Preliminary clinical study of the treatment of Kasrate-Tams (menorrhigie) with tukhm-e-bartang (Plantago major Linn.). J Res Indian Med Yoga Homeopathy.1979;14:1-6. https:// doi.org/10.1016/S0378-8741(00)00212-9

56. Kapur SK. Medico-botanic survey of medicinal and aromatic plants of Mawphlang (Shillong). Indian Drugs. 1983;21:1-5.

57. Rao RR, Jamir NS. Ethnobotanical studies in Nagaland. I. Medicinal plants. Economic Botany. 1982;36:176-81. https://doi.org/10.1007/BF02858714

58. Rao RR. Ethnobotany of Meghalaya: medicinal plants used by Khasi and Garo tribes. Economic Botany. 1981;35:4-9. https://doi.org/10.1007/BF02859208

59. Tiwari KC, Majumder R, Bhattacharjee S. Folklore medicines from Assam and Arunachal Pradesh (District Tirap). Int J Crude Drug $\quad$ Res. 1979;17:61-67. https://doi.org/10.3109/13880207909067450

60. Emmy DC, Kateřina H, Patrick VD. Tamarindus indica L.: A review of traditional uses, phytochemistry and pharmacology. Afrika Focus. 2010;23(1):53-83. https://doi.org/10.21825/af.v23i1.5039

61. Prakash OM, Chandra M, Pant AK, Rawat D S. Mint (Mentha spicata L.) oils In: Preedy RV (ed). Essential Oils in Food Preservation, Flavor and Safety, San Diego, Academic Press; 2016. https://doi.org/10.1016/B978-0-12-416641-7.00064-X 
62. Siemonsma J, Piluek K. Plant Resources of South-East Asia Indonesia, Bogor;1994.

63. Singha HR, Singha S, Singha RK. Comparative cytological and fruit biochemical studies in two populations of Solanum torvum Sw. an ethnobotanical species of Northeast India. Taiwania. 2018;63(2):1010-105 https://doi.org/10.6165/tai.2018.63.101

64. Mahanta S, Sarma R, Khaniker B. The essential oil of Lippia alba Mill. (Lamiales: Verbenaceae) as mosquitocidal and repellent agent against Culex quinquefasciatus Say (Diptera: Culicidae) and Aedesa egypti Linn. (Diptera: Culicidae). J Bas Appl Zool. 2019;80(64):1-7. https://doi.org/10.1186/s41936-0190132-0

65. Pascaul E, Karla S, Carretero E, Villar A. Antiulcerogenic activity of Lippia alba (Mill.) N. E. Brown (Verbenaceae). Farmaco. 2001;56(5-7):501-04. https://doi.org/10.1016/S0014827X(01)01086-2

66. Caceres AA, lvarez AV, Ovando AE, Samayoa BE. Plants used in Guatemala for the treatment of respiratory diseases screening of 68 plants against Gram-positive bacteria. J Ethnopharmacol. 1991;31:193-208. https://doi.org/10.1016/0378-8741(91)90005-X

67. Adjatin A, Dansi A, Badoussi E, Sanoussi AF. Proximate, mineral and vitamin C composition of vegetable Gbolo [Crassocephalum rubens (Juss. ex Jacq.) S Moore and C. crepidioides (Benth.) S Moore] in Benin. Int J Biol Chem Sci. 2013;7(1):319-31. https://doi.org/10.4314/ijbcs.v7i1.27
68. Sinha B, Controlling COVID-19: Learnings from the Northeast India, Development Review. Retrieved from https://idronline.org/controlling-covid-19-learnings-from-thenortheast/(2020)

\section{Additional information}

Peer review information: Plant Science Today thanks Sectional Editor and the other anonymous reviewers for their contribution to the peer review of this work.

Reprints and permissions information is available at

https://horizonepublishing.com/journals/index.php/PST/open_access_policy

Publisher's Note: Horizon e-Publishing Group remains neutral with regard to jurisdictional claims in published maps and institutional affiliations.

To cite this article: Nakhuru K S, Lokho A, Barman M, Das J, Dwivedi S K. Evaluation of vitamin $C$ in ethno-wild edible plants in Northeast India. Plant Science Today. 2021;8(2):473-481.

https://doi.org/10.14719/pst.2021.8.2.1100

Plant Science Today, published by Horizon e-Publishing Group, is covered by Scopus, Web of Science, BIOSIS Previews, Clarivate Analytics, etc. See https://horizonepublishing.com/journals/index.php/PST/indexing_abstracting 